\title{
REFLEXÕES PARA A PRÁTICA CLÍNICA ÉTICA-ESTÉTICA-POLÍTICA A PARTIR DA ARTE DE ERNESTO NETO
}

\author{
Fernando Silva Teixeira Filho \\ Universidade Estadual Paulista "Júlio de Mesquita Filho" \\ Murilo Galvão Amancio Cruz \\ Universidade do Estado do Rio de Janeiro
}

\begin{abstract}
Resumo
Este artigo propõe uma articulação entre arte contemporânea e clínica psicológica a partir da obra de Ernesto Neto. Auxiliados pelas perspectivas feministas e filosóficas pós-estruturalistas, problematizamos a clínica a fim de propor uma prática éticaestética-política voltada às interrupções dos modos de produção de subjetividade que normatizam a existência, e substituí-los pela produção de estados de arte que estimulam as diferenças e singularizações. Assim, abordaremos quatro pilares de problematização: a) arte e clínica; b) arte e estudos feministas; c) arte e filosofia; d) arte e corporeidade. A obra de arte contemporânea possibilita aos sujeitos repensarem sua relação com o mundo, mostrando um espaço de fuga do cotidiano, em que o sujeito deixa de pensar para respirar a própria vida pela via da sensação e não mais pela razão. Assim, o sujeito é convidado a forçar o pensamento a pensar pelo sentir e não pelo representar.
\end{abstract}

Palavras-chave: Clínica; Arte Contemporânea; Subjetividade; Sensação; Corporeidade.

\section{REFLECTIONS FOR AN ETHIC-AESTHETIC-POLITICAL CLINICAL PRACTICE THROUGH ERNESTO NETO'S WORK OF ART}

\begin{abstract}
This paper proposes a link between contemporary art and clinical psychology inspired by Ernesto Neto's work. Trough feminist and post-structuralist philosophical perspectives, we raise clinical issues to propose an ethical-aesthetic-political practice aiming to interrupt the modes of production of subjectivity, which normalize the existence, and to substitute them for the production of modes of art that stimulate differences and singularizations. Therefore, we follow four pillars of questioning: a) art and clinical practice; b) art and feminist studies; c) art and philosophy; d) art and corporeality. Contemporary art allows the subjects rethink their relationship with the world, opening up possibilities for a daily escape space, in which the subject stop thinking to feel life itself through sensation but not reasoning. So the subject is asked to think by means of feeling, not of representation.

Keywords: Clinic; Contemporary Art; Subjectivity; Sensation; Corporeality.
\end{abstract}




\title{
REFLEXIONES PARA LA PRÁCTICA CLÍNICA ÉTICA-ESTÉTICA-POLÍTICA DESDE LA ARTE DE ERNESTO NETO
}

\begin{abstract}
Resumen
Este trabajo propone un vínculo entre el arte contemporáneo y la psicología desde la obra de Ernesto Neto. Ayudado por la perspectiva filosófica post-estructuralista, problematizamos la clínica a fin de proponer una práctica ética-estética-política orientada a las interrupciones de procesos de producción de subjetividad que regulan la existencia, para incitar la producción de estados de arte que estimulan las diferencias y singularizaciones. Seguiremos cuatro reflexiones: a) el arte y la práctica clínica; b) estudios de arte y feministas; c) el arte y la filosofía; d) el arte y la corporalidad. El arte contemporánea permite que los sujetos replanteen su relación con el mundo, posibilitando un espacio de escape diaria, en la que el sujeto impensa a pensar la vida no más pela razón más pela sensación. Entonces, se pide al sujeto que forcé la mente para pensar pela sensación e no pela representación.
\end{abstract}

Palabras clave: Clínica; Arte Contemporáneo; Subjetividad; Sensación; Corporalidad.

\section{INTRODUÇÃO}

O objetivo deste artigo é apontar e refletir sobre possíveis articulações entre a arte contemporânea e a clínica psicológica, tendo como pano de fundo a obra do artista Ernesto Neto. Auxiliados pelas perspectivas feministas e filosóficas pós-estruturalistas, ensaiaremos algumas problematizações fundamentais à clínica. Pretendemos expor, portanto, como a arte contemporânea expressa na obra deste artista pode auxiliar a prática de uma clínica ética-estética-política voltada efetivamente às interrupções e/ou extinção dos modos de produção de subjetividade que normatizam a existência, tendo como efeito, a produção de estados de arte nos engendramentos de subjetivação que estimulam e preservam as diferenças e as singularizações.

Edgar Morin coloca-nos uma reflexão necessária a ser feita no contemporâneo: "como adquirir a possibilidade de articular e organizar as informações do mundo?" (Morin, 2003, p. 70). Segundo o autor, isso só se alcançará a partir de uma reforma do pensamento. Criticando os séculos de racionalismo como princípios da epistemologia moderna, Morin (2003) sugere a utilização de um pensamento complexo, que seja capaz de reunir (contextualizar e globalizar) sem perder de vista a incerteza como elemento constituinte do conhecimento. Já em Freud assistíamos a uma proposta de conhecimento via clínica que contava com um além da consciência como topos de gestação do conhecimento. Tratava-se ali de um saber inconsciente. Não fosse o seu projeto metapsicológico de trazer à consciência o inconsciente, poder-se-ia argumentar que a psicanálise freudiana não é racionalista em sua natureza (Mezan, 2007). Pode-se dizer que o estruturalismo, sobretudo o lacaniano, resgata em Freud este primado do não-saber como o lugar e fonte do conhecimento, avesso, portanto, à proposta racionalista de trazer à consciência o inconsciente. $O$ problemático aí, entretanto, foi afirmar que a presença da falta seja não só o componente epistemológico, mas também seu componente estruturante. Em um processo dialógico, tem-se, por fim, que a incerteza deriva de uma falta-a-ser 
como estrutura a qual instauraria o desejo de conhecer, o desejo de vir a ser, de tornar-se. A pergunta que se impõe, entretanto é: tal desejo necessariamente se originaria a partir de uma falta? Não haveria conhecimento derivado de excessos? A ideia de um conhecimento advindo de excessos nos parece muito próxima desta complexidade proposta por Morin (2003). Segundo ele: "O pensamento complexo é, portanto, essencialmente, o pensamento que lida com a incerteza e que é capaz de conceber a organização" (Morin, 2003, p.77) reunindo as partes, as singularidades como fazendo parte de um todo, mas sem que se reduza à formula: o todo é a somatória das partes. Não, o todo não é integrado, já que as partes não necessariamente dialogam entre si, mas sem necessariamente dizer que seriam independentes do todo no qual se manifestam. Com efeito, o que caracteriza, atualmente, o contemporâneo é sua complexidade. $\mathrm{E}$, para lidar com esta complexidade a ciência necessita também de pensamentos que a afirmem, isto é, que una partes distintas, singulares, heterogêneas sem perder a dimensão do contexto nos quais elas se localizam.

Com efeito, o artista em questão pode ser pensado como contemporâneo não apenas por sua posição cronológica frente ao tempo, mas, sobretudo, por suas propostas artísticas que transcendem o espaço privado do museu para ocupar galerias cotidianas onde a interação [obra e público] é imprescindível. De fato, a arte contemporânea difere da obra de contemplação característica das artes que antecederam à modernidade, mas que, ainda neste período, podemos encontrar remanescentes. As artes modernas, capturadas pelo capitalismo, ainda são "consumíveis", ainda nos apresentam "respostas" de antemão, deixam pouco espaço às incertezas. Já no contemporâneo, a obra de arte não tem valor no eterno da obra; ao contrário, quando há objeto artístico (e raramente há), em sua efemeridade, o que se busca não é a sua contemplação ou consumo, mas um ato de "fazer o pensamento pensar", ou seja, o público é obrigado a deslocar-se, sair do lugar, desconstruir o que já conhece e é convidado a criar junto com o processo proposto pela ação do artista. Esse convite não se faz sem a instauração da incerteza ou simplesmente do prazer em inventar por inventar, em fabular, em fugir do estabelecido e viajar outros territórios de possíveis.

Segundo Foster (2001), especialmente no quinto capítulo de seu eloquente livro, O retorno do real, encontramos uma interpretação interessante sobre o modo como a arte contemporânea (pós-moderna) é concebida: ela é essencialmente traumática. Tomando Andy Warhol como representativo deste elemento traumático, Foster nos fornecerá elementos para pensar que o traumático é justamente o dar visibilidade ao modo serializado de produção de subjetividades que Warhol não apenas "retrata" em suas obras, mas também as produz. Ele dirá:

[...] as repetições de Warhol não apenas reproduzem efeitos traumáticos; também os produz. De alguma maneira, nessas repetições, então, ocorrem ao mesmo tempo várias coisas 
contraditórias: uma proteção da significação traumática e uma abertura a ela, uma defesa contra o afeto traumático e uma produção do mesmo (Foster, 2001, p. 134, tradução nossa).

Tomando como base o modelo lacaniano de inconsciente como repetição, ele conclui que, por repetir o real, a obra de arte é traumática; uma repetição que não revive nenhum passado recalcado, mas, ao contrário, cria uma temporalidade (sem narrativa) ao mesmo tempo em que revela o que é, no contemporâneo, abjeto, ou seja, excluído. Seria este o engajamento éticoestético-político da arte contemporânea? Buscar revelar, representar ou dar representatividade ao real, ao abjeto que, por construção lógica, não podem jamais serem representados, pois que excluídos? A saída desse paradoxo parece indicar um deslocamento do olhar: não se trata de representar, mas sim de produzir traumas, aqui vividos como possíveis saídas, fluxos, linhas de fuga ao excesso de repetições de imagens que esvaziam os significados das coisas, dos valores, das crenças, dos desejos. Não é, portanto, um conteúdo que se repete, mas sim uma imagem, um ato que afirme a experiência traumática. Em outros termos, o que se repete no ato criativo não é uma cena, uma narrativa, mas a instauração do acontecimento traumático como chave de produção de novos possíveis nada, ou minimamente, serializados; nem que para isso, pelo menos nos anos 1990, alguns artistas tenham tido que resgatar uma perversidade (contestação à lei) a partir do que parecia ser uma apologia à "merda" como crítica ao falocentrismo, heterosexismo, primazia machista e branca que dominavam (e ainda dominam) os sentidos e significados do existir nas sociedades capitalistas atuais. Segundo este autor, portanto,

$\mathrm{Na}$ arte contemporânea o desafio erótico-anal é com frequência autoconsciente, inclusive autoparódico: ele não apenas coloca à prova a autoridade analmente repressiva da cultura museológica tradicional (que é, em parte, uma projeção edípica), mas também ridiculariza o narcisismo analmente erótico do artista-rebelde de vanguarda (Foster, 2001, p. 165, tradução nossa)

Assim, afinados a estas considerações, podemos dizer que na arte contemporânea o importante não é dar respostas, mas antes, lançar perguntas, criticar, descolonizar os saberes e propor caminhos que desloquem os espectadores e artistas a pensarem novos meios de se posicionarem no mundo e de problematizá-lo em seu cotidiano.

É nesta perspectiva que apresentaremos nossas articulações com a obra de Ernesto Neto, visando estabelecer um diálogo entre seu trabalho e a noção de arte contemporânea para, enfim, refletirmos sobre as relações possíveis entre arte e outros campos do saber, especificamente, a clínica psicológica. Para tanto, seguiremos uma linha de raciocínio que tem como referência quatro pilares de problematização que nos auxiliam neste trabalho: arte e clínica; arte e estudos feministas; arte e filosofia; arte e corporeidade. 


\section{SOBRE ERNESTO NETO}

Ernesto Neto nasceu em 1964 no Rio de Janeiro. É um artista contemporâneo ainda vivo que desde a década de 1980 tem surpreendido espectadores com o seu modo próprio de fazer arte. Ele mistura uma produção escultural e de instalação para criar, sobretudo, por meio de tecidos elásticos, temperos e especiarias, isopor, e contando com a própria força da gravidade, uma interação sensorial e cinética entre o espectador e a obra, já que aquele adentra às formas orgânicas criadas pelo artista e com elas se relaciona. Suas esculturas aludem ao corpo humano visto por dentro, desde o material do qual são feitas, que se assemelha à epiderme, até as suas próprias formas viscerais. Assim, o espectador pode se relacionar com a representação da paisagem interna do seu organismo, misturando-se entre o dentro e o fora como se caminhasse por debaixo de um jardim suspenso.

O artista tem, no início de sua carreira, as referências de José Resende (1945) e Tunga (1952-2016), que o influenciaram na exploração da articulação formal e simbólica de diversas matérias. Posteriormente, ao aprimorar seu trabalho, começa a compor uma singularidade e passa a criar seu próprio estilo, marcado por elementos do cotidiano como meias de poliamida e outros materiais flexíveis e especiarias do dia-a-dia. Assim, por volta da década de 1990, realiza esculturas com tubos de malha fina e translúcida, preenchidos com especiarias de diversas cores e aromas. Tais esculturas são formadas por estruturas de tecidos transparentes que podem ser penetradas pelo público, o qual interage ativamente com suas obras. Podemos dizer que a partir deste período, o corpo humano assume lugar central em seu trabalho, inclusive nos títulos de suas exposições tais como: O céu é a anatomia do meu corpo ou Acontece na friç̧ão dos corpos, ambas de 1998, Humanoides (2002), Não tenha medo de seu corpo (2012), El cuerpo que me lleva [O corpo que me leva] (2014). Um exemplo de sua obra pode ser visto em sua exposição denominada Madness is part of life [A loucura é parte da vida], exibida em Tóquio no ano de 2012 (o que pode ser conferido no site: http://www.designboom.com/art/ernesto-neto-madness-ispart-of-life). Nesta exposição, o autor utiliza de linhas de crochês suspensas, que sustentam bolas de plástico e formam um grande organismo pelo qual o público interage em movimento.

Suas obras, portanto, criam espaços de intercâmbio que exigem do espectador mais que uma experiência de contemplação, mas, antes, de interação, onde seus sentidos serão aguçados e os corpos do espectador e da obra de arte tornam-se mútuos protagonistas que fundam o eixo principal de sua proposta: a criação da obra na interação dialógica, na relação fluída entre os elementos interagentes e singulares. Trata-se de uma obra que se organiza na própria interação e no caminhar com e sobre ela, deve-se apresentar uma introdução ao método. 


\section{A ARTE CONTEMPORÂNEA}

A arte contemporânea é marcada por uma mudança de paradigma estético (Guattari, 1992), sobretudo, frente à relação entre o espectador e o objeto de arte. Enquanto na arte moderna, a relação espectador e objeto de arte é pautada pela contemplação de uma obra, quase sempre distante e provida de um grande valor material, na arte contemporânea a relação entre espectador e objeto é marcada pela interação entre público e obra, onde as linhas que limitam um e outro se tornam mais tênues, quase imperceptíveis e o objeto, não mais distante e agora desprovido de valor material, pode ser qualquer coisa. Isto é, qualquer coisa passa a ser uma possibilidade de tornar-se objeto de arte e artista na medida em que a arte não é mais um objeto de valor que deve permanecer no museu para contemplação, mas sim um objeto que adentra o cotidiano das pessoas e as implica no próprio processo de produção artística.

Com efeito, de acordo com Rolnik (2001), o artista contemporâneo é aquele que amplia o trabalho com a matéria do mundo e toma a liberdade de explorar diferentes materiais que compõem o mundo, explorando assim outros modos de invenção da arte. Destarte, a arte torna-se assim uma prática de problematização que depende da interferência direta com o espectador e, portanto, com o mundo subjetivo e social de cada um.

Portanto, o que muda e se radicaliza na arte contemporânea é que, ao trabalhar qualquer material do mundo e interferir nele diretamente, se explicita de um modo mais contundente que a arte é uma prática de problematização (deciframento de signos e produção de sentido), uma prática de interferência direta no mundo. $\mathrm{E}$, justamente, é nesta interferência na cartografia vigente que atua a prática estética, sendo a forma indissociável de seu efeito de problematização do mundo (Rolnik, 2001, p. 6, tradução nossa).

De fato, não estamos mais situados no momento de reprodução e representação das formas dadas, mas sim em um campo de trabalho onde a potência de variação e de criação estão abertas ao novo, ao inventivo, a aquilo que foge e rompe com o esperado e o pronto. Os signos são decifrados em mutações sensíveis que se reinventam e transformam o próprio mundo (Rolnik, 2001). Portanto, na arte contemporânea, todos os elementos são transformados: os espaços, os objetos, as personagens, o público, a maneira pela qual se expõe ao público, tudo se torna inventivo e interativo.

Com efeito, para Rolnik (2015), "a arte é o campo privilegiado de enfrentamento do trágico" (p. 104), já que o modo de subjetivação artista do qual fala Rolnik (2015), inspirada no trabalho de Lygia Clark, possibilita uma escuta das diferenças intensivas que vibram em seu próprio corpo e proporcionam a restruturação de um novo eu e a morte do eu atual. Assim sendo, o artista contemporâneo ao se transformar também transforma o mundo já que o receptor da obra terá a possibilidade de ampliar-se subjetivamente neste encontro, ou seja, de transformar também o seu corpo-vibrátil - conceito 
trabalhado por Rolnik ao longo de seus escritos e que parece-nos muito pertinente aqui já que a obra de Neto suscita tanto a percepção das formas corporais, suas representações (vísceras, esôfagos...), que tratam do corpoorganismo, mas também de suas forças (os movimentos peristálticos, autônomos), que despertam o corpo-vibrátil, portanto, das sensações - em outra coisa diversa da anterior: é, de fato, a incerteza da criação pela via da expressividade. Suas obras, portanto, borram os limites perceptíveis das representações e amplificam os territórios expressíveis dando consistência, portanto, ao corpo-vibrátil feito justamente desta matéria expressiva, que não pode ser representada.

É sob esta perspectiva que trazemos para reflexão os trabalhos de Ernesto Neto. É possível afirmar que a exploração de diversos binarismos presentes na vida, como o masculino/feminino, a imanência/transcendência, interior/exterior, apareça em seu trabalho a partir de complementos como nas obras Barrabola (1987), Chapa-Corda-Chapa (1987), Leviathan Thot (2006) - onde o panthéon e a escultura tornam-se complementares. A dicotomia é, então, um dos aspectos comumente presente na obra deste artista, inclusive na problematização que implica o sujeito-espectador em sua obra e o convida a se retirar do lugar (algumas destas obras podem ser consultadas em http://www.ppgav.eba.ufrj.br/wpcontent/uploads/2012/01/ae16_entrevista_ernesto_neto.pdf).

\section{ALGUMAS REFLEXÕES}

A partir desta breve introdução sobre a obra de Ernesto Neto e sua relação com a arte contemporânea, pretendemos explorar algumas reflexões em torno da articulação de sua obra com a clínica psicológica. Para fins de maior clareza neste texto, dividimos em quatro grandes temas: a) Arte e Clínica; b) Arte e estudos feministas; c) Arte e Filosofia; d) Arte e Corpo.

\section{Primeira reflexão}

Como vimos, na arte contemporânea, o/a espectador/a é convocado/a em toda sua subjetividade a participar ativamente do processo de arte. Assim, de acordo com Rolnik (2001), o/a espectador/a capta todas as sensações provocadas por esse contato com a diferença e se transforma. Todavia, esta não é a priori uma experiência psicológica, mas a experiência da relação da subjetividade do/a espectador/a com o mundo. Retomando o trabalho de Lygia Clark, Rolnik (2001) afirma "Sem dúvida, encontramos aqui o mais disruptivo desta proposta: a realização da obra implica a mobilização da subjetividade do receptor, de sua potência para vibrar diante das intensidades do mundo e decifrar os signos formados por suas sensações" (Rolnik, 2001, p. 8, tradução nossa). 
Com efeito, é neste encontro e deciframento dos signos produzido pela ação artística, o qual sempre vem acompanhado de um "mal-estar", um deslocamento de sentidos, que há uma reativação da dimensão não psicológica da subjetividade e podemos dizer, embora soe paradoxal, que esta dimensão não psicológica é justamente a dimensão clínica da arte. Nesse sentido, a articulação entre arte e psicologia está relacionada a esta sensação produzida pelo nosso corpo-vibrátil (Teixeira-Filho, 2012).

A dimensão não psicológica da subjetividade é clínica e pode ser também alcançada pelas intervenções artísticas na medida em que não são os aspectos trabalhados pela psicologia e psiquiatria científica desde o século XVIII que são tratados, mas, antes, os aspectos sensíveis, isto é, as sensações propriamente, tendo a criação como uma ferramenta de se relacionar com o mundo. Afinal, de acordo com Rolnik (2001), as ciências psicológicas surgem para dar conta dos efeitos colaterais de um modo historicamente datado de subjetivação, que se caracteriza pela redução do psiquismo à sua dimensão psicológica e a proscrição da dimensão estética. Neste contexto, por aspectos da vida compreendemos, de um modo amplo, aquilo que não está capturado pelo discurso de um suposto aparelho psíquico e seus correlatos; e de um modo mais específico, tratamos aqui das sensações, disto que permeia o pré-subjetivo, que é impessoal.

Podemos dizer que a consciência origina uma linguagem que funciona como mediadora das experiências humanas. Essa linguagem apresenta uma lógica representacional que afasta a processualidade justamente porque procura re-produzi-la, ou melhor, re(a)presentá-la. Este fato faz com que a natureza processual da subjetividade humana, que é sua natureza diferenciadora, termine por aterrorizar a consciência [acerca do terror sentido pela consciência em relação à processualidade, conferir Rolnik (1995)]. Esta consciência, tentando defender-se do terror causado pelo novo, passa a re-produzir experiências já vividas via linguagem. Tal reprodução das mesmas experiências desloca a subjetividade de seu lugar junto ao que se vive, ou antes ao devir da existência e a faz funcionar por remetimento a modelos de existência previamente experenciados (Bergson, 1990). Segue-se que a subjetividade humana pode cristalizar-se na ideia de indivíduo e imaginar-se superior em relação à processualidade e às outras formas de subjetivação existentes no Planeta (subjetividade poeta, planta, etc., por exemplo), justamente por que é capaz de memorizar suas experiências passadas e repeti-las. É neste momento que, aterrorizado diante da processualidade, o ser humano erige um Eu que funciona como ponto de referência identitário. A função desse Eu é a de (re)produzir uma sensação de equilíbrio e controle da processualidade de experiências heterogêneas pela re(a)presentação do vivido.

Assim, é a partir da ideia de criação como processualidade de fluxos heterogêneos infinitos que produzem agenciamentos finitos (cujo efeito é reenviar a subjetividade humana ao seu contato imediato com o devir), que 
tentamos compreender a natureza e a lógica dessa processualidade no plano de composição artística.

Antes de ser o território das belas formas ou das belas sensações, a arte é o território das sensações e formas puras. Cada obra de arte é um bloco de sensação (Deleuze \& Guattari, 1992). Tais blocos se distinguem um dos outros, conforme os planos de composição que cada artista se propõe a realizar. Evidentemente, a sensação isolada em cada bloco é imaterial em si e é ela mesma que justifica a existência não intencional da obra, não enquanto uma bela sensação, mas enquanto uma pura sensação, isto é, uma sensação bela.

Sensações tais como o toque antes do tato, o som antes do barulho, o paladar antes do gosto, o peso antes do objeto pesado, o grito antes do horror, o calor antes do fogo (e outras), não são percebidas a olhos nus. Trata-se de um olhar mais sensível e menos cerebral. Elas se imbricam na matéria e produzem uma forma pura. No caso da arte, a matéria entra na sensação. Deste encontro nascem formas (materialidades) que sustentam as sensações. E são estas formas que atribuem o valor estético à sustentação das sensações inventadas. Este encontro produz vicissitudes infinitas, podendo ser apresentado pelas palavras (literatura), pelos gestos (dança), pelas tintas (pintura), pelos sons (música) e outros. Assim, por exemplo, os materiais do pintor (a tela, a tinta, os pincéis etc.), não têm a função de mediadores entre a subjetividade humana e a experiência. Eles são instrumentos de ação do pintor. Eles são ato, presença, e corpo com vida própria (Bergson, 1979). A linguagem que a obra de arte contemporânea produz não apresenta uma lógica representacional porque os materiais que formalizam a sensação não servem para expressá-la ou reproduzila, mas sim para sustentar sua enunciação. Uma obra de arte não re-produz vivências (não narra fatos ou tampouco se repete), porque ela é, per si, uma vivência, ou antes uma produtora de vivências. A linguagem que uma obra de arte efetua é regida pela lógica da sensação. Tal lógica é imediata: ela não reproduz experiências, mas produz experiências e já é, ela mesma, uma experiência.

A sensação é imanente ao plano de composição artística, por isso existe independentemente do remetimento a uma representação (modelo transcendente) que venha a ocupar o lugar desta falta. Além disso, a sensação da qual se fala aqui, ocorre ao ser humano e não parte dele, não vem dele; antes, é uma sensação produzida com ele sendo um elemento nesta composição sensacionista. A sensação não é algo que sai do ser humano, mas antes, algo que Ihe chega, Ihe afeta e o inclui como elemento. Assim pensada, a sensação não tem nada a ver com a biografia, com a personalidade ou com a individualidade de alguém.

A sensação está isolada em cada obra de arte e em toda forma de arte. Esta sensação isolada produz afectos que afectam o espectador e lhe causam a surpresa. Tais afectos implicam, também, o encontro do êxito na forma e o êxito 
do belo. De onde o espectador se torna a testemunha de que em cada obra de arte há sensações afirmadas (Diamond, 1990).

Eduardo Cardoso Braga, em breve reflexão sobre a arte como produtora de sensações e o tratamento que Gilles Deleuze dá a este conceito em sua obra, assim resume:

Desta forma, a arte é autônoma, possui suas próprias leis e cujas
relações internas a conduzem para o eterno Devir e, por isso mesmo,
capaz de provocar uma profunda sensação em quem a desfruta. Esta
é uma interpretação contemporânea da produção artística, definindo
a arte como potencialmente capaz de produzir um choque, uma
desestabilização temporária dos processos perceptivos, uma
desterritorialização dos conceitos. Deleuze, ao refletir sobre a obra de
Francis Bacon fornece um modelo estético mergulhado na
experiência, sem, contudo, cair em subjetivismos ou psicologismos,
que diminuem a autonomia do objeto artístico. Esta abordagem é
especialmente interessante nos dias de hoje, pois temos observado a
arte cair num excesso de abstração pseudoconceitual, num eterno já
visto, destituído de memória e desprezando a experiência imediata.
Colocar a arte na esfera da sensação revitaliza o seu poder de
expressar e desestabilizar, obrigando uma desterritorialização
conceitual e existencial (Braga, 2004, p. 5).

Retomar a subjetividade para além do psiquismo é corporificar esta subjetividade. Todavia, não é como pretendem algumas outras ciências médicas, que visam corporificá-las no substrato anatômico; é encarná-las no corpo todo, afinal somos corpos que vibram seja por sensações neurológicas seja por sensações estéticas (pontos de tensão entre a representação e o Devir), e este aspecto está presente em todo momento na obra de Neto. O artista critica a divisão cartesiana mente versus corpo e a supervalorização da mente, e traz nossa corporeidade à tona demonstrando como somos corpos em todos os aspectos e em todas as relações. É por isso que sua obra retoma o contato corporal entre o corpo do espectador e o corpo da obra de arte.

Em 2012, o artista apresentou sua obra Não tenha Medo do seu Corpo na galeria e no galpão da Fortes Vilaça, em São Paulo. E nesta ocasião afirmou: "Considero muitos dos trabalhos que faço como esculturas-aventuras, onde o corpo é o protagonista" (citado por Lopes, 2012, 30 parágrafo). Assim, criando escadas e passarelas para que as pessoas ocupem os mais diferentes espaços e possam observar a obra de diferentes perspectivas, o artista compôs a partir de crochê, cordas e força da gravidade um ambiente de experiência corporal do público com sua obra. É interessante notar o quão está rompida a dicotomia dentro/fora nas obras do artista. Tal como a pele humana, a pele de suas esculturas também é permeável e penetrável.

Assim, podemos pensar que a vivência desta arte - tal como acontece na obra de Lygia Clark trabalhada por Rolnik (2015), a partir de exemplos como $A$ casa é o corpo e Baba Antropofágia -, pode desmanchar nosso contorno e nossa própria imagem corporal já que ao entrarmos em contato com a obra do artista, 
a sensação é de pertencimento, ou seja, de não haver limite entre corpo do espectador e corpo da obra. É assim que a obra tem o poder de ultrapassar o campo artístico para adentrar diversos outros aspectos da vida. É produzir o que Lygia Clark (Rolnik, 2015) chamou de estado de arte, ou seja, aquilo que faz gritar a subjetividade e a resistência, que faz "grasnar o corpo-bicho".

Assim, utilizando, sobretudo, da escultura, o artista confronta o espaço, pois é nele que há a relação indissociável entre sujeito e espaço. Na visão do artista, sujeito e espaço não existem independentes. E assim o artista cria uma geometria hipersensível, influenciado por Lygia Clark e suas "linhas orgânicas", e transforma o próprio sujeito em linha que costura a obra e se costura (Rivera, 2013).

Com efeito, acreditamos que Ernesto Neto alcance o estado de arte sem arte ao criar condições para desgrudar a subjetividade de um dentro absoluto, interiorizado em identidades. A proposta de Lygia ao falar sobre "atingir o singular estado de arte sem arte" diz respeito à capacidade de atingir os próprios processos de subjetivação do público e da obra-artista, superando as perspectivas de um dentro particular e identitário, como um psiquismo interiorizado no cérebro do sujeito, para assumir uma perspectiva instável de um corpo sem forma e contornos definidos (Rolnik, 1998). A proposta, portanto, de retirar a arte da palavra é o próprio espírito da arte contemporânea, isto é, a proposta de que podemos alcançar estados de arte na própria experiência da existência dos sujeitos no cotidiano e, para além do cotidiano, até mesmo nas práticas psicológicas. Deste modo, a obra do artista convida o tempo todo resgatar a vida em sua própria potência criadora. E este é para Rolnik (2001) o único aspecto possível de uma noção de "cura": a afirmação da vida como força criadora.

\section{Segunda Reflexão}

Embora Ernesto Neto não tenha trabalhado diretamente com questões que envolvessem gênero e/ou a luta LGBT, o artista está sutilmente ligado a essas questões quando traz sempre à tona em suas obras a problematização dos binômios, como ele mesmo afirma, ou dicotomias, onde a questão de gênero certamente ainda repousa. Como o próprio artista afirma em entrevista a respeito de suas esculturas:

(...) de alguma forma essas esculturas me deram respiração e independência. Acima de tudo, elas traziam, de um jeito mais literal, conceitos básicos do meu trabalho, a relação do dentro e fora, do corpo e do contorno do corpo, da realidade e da fantasia, do masculino e do feminino (Neto, 2008, p. 10).

Feix (2007) ao discorrer sobre a inscrição do masculino e do feminino na arte traça um percurso histórico sobre o campo da arte protagonizado pelas mulheres e pelas teorias feministas, destacando também a representação da mulher e do homem pelos artistas ao longo da história. Feix (2007) apresenta a 
obra da escritora francesa Anne Garréta que conseguiu resistir em sua escrita ao aprisionamento do gênero binomial, quando escreve um romance sem determinação de gênero dos personagens. Com efeito, a artista pretende se libertar dos estereótipos aprisionantes do gênero e/ou da arte feminina assinando também sua obra com um pseudônimo sem determinação de gênero.

Assim, pensando na representação de homens e mulheres no decorrer da história da arte, podemos relacionar à representação de corpo que Ernesto Neto traz em suas obras suspensas. Podemos afirmar que em todas suas obras onde $o$ corpo é representado este nunca possui um atributo de gênero. É como se o nosso corpo de espectador/a adentrasse um corpo onde as relações de poder que sustentam as relações de desigualdades de gênero já estivessem superadas, pois o contato com este corpo orgânico afirmado na obra de Neto não apresenta nenhuma característica peculiar aos gêneros, tal como os entendemos. Ou seja, em suas obras não vemos performances de gênero (Butler, 2003) e tampouco genitalização do corpo. Todavia, como apresentamos anteriormente, as questões dos binômios estão presentes em sua obra, portanto, dizer que a obra não apresente questões de gênero não quer dizer que não coloque os/as interagentes para pensar. Decerto, as questões de gênero aparecem em seus binômios como elementos complementares. Ademais, a própria ausência de sexo e explicitação de gênero em suas obras desterritorializam as representações normatizadas e normatizadoras dos interagentes. Assim, ainda que não queiram voluntariamente refletir sobre a questão, essa se lhes aparecerá como uma compulsão, um ato involuntário na tentativa de se reterritorializarem, de se localizarem geopoliticamente na relação com a obra e na tentação de serem capturados pelos discursos de gênero, por exemplo, pensando, dizendo: "aqui estou, homem (ou mulher) interagindo com este corpo (sem gênero, sem sexo)? Como devo me comportar? E se, na interação, eu sentir prazer? Devo revelá-lo? Mas, e se ao final descobrimos que se trata de um corpo também masculino?"

Com efeito, para Butler (2003), o gênero é uma categoria identificatória do corpo produzida pela sociedade, ou seja, o gênero está encarnado em um corpo e o generifica, mas apenas em sua relação com outro significado - social, cultural e histórico. Em outros termos, para Butler o gênero não é algo que temos, que nascemos com ele. Antes, fiel ao pensamento de Simone de Beauvoir que diz que "não nascemos mulher (ou homem), mas nos tornamos", o gênero é algo que realizamos, que fazemos todos os dias, isto é, que o performamos e repetimos cotidianamente ao ponto de o naturalizarmos. Assim, sem percebermos, o gênero torna-se "fato", uma categoria de organização afetivopolítica-ética-estética-social. Na obra de Neto, podemos afirmar que o gênero não está encarnado no corpo da obra de arte, pois este não apresenta uma relação de poder social, cultural e histórico, mas um poder reflexivo que parte das subjetividades que adentram este corpo artístico. De fato, é como afirma Lucy Lippard (citada por Trizoli, 2008), a arte feminista não é um movimento 
estético dentro da arte, mas um modo peculiar de interagir com o mundo. $\mathrm{E}$ neste ponto, acreditamos que Neto converge às temáticas de problematização do gênero ao não aprisionar suas esculturas aos gêneros, outrossim, ao colocar em xeque as dicotomias nos possibilita outras formas de relações com os corpos, 0 que pode nos ajudar a colocar em prática interações minimamente atravessadas pelas desigualdades entre as categorias sociais de diferença (raça, etnia, classe social, nível educacional, geração, etc.).

\section{Terceira Reflexão}

Ernesto Neto afirma em vídeo (Sesc TV, 2014) que o que lhe interessa é o humano. Afetar o/a espectador/a para que este/a saia de seu conforto, de seu território habitual. Em outras palavras, podemos dizer que o que interessa para Neto é que o universo privado de seu público se desterritorialize. É o que podemos aferir de sua última exposição na Espanha El cuerpo que me lleva (2014), onde traz um pouco de cada uma de suas exposições desde 1989 . O artista constrói um mundo em que o público é convidado a entrar. Lá encontramos um teto feito de crochê e que sustenta gotas, árvores, tambores, apitos e chocalhos, que permanecem suspensos no ambiente. Encontramos também um grande ectoplasma composto de nylon e miçangas, que guarda objetos para troca com o público. Em outra sala com os dizeres "não repara não", o artista cria um ambiente mais íntimo, em que um grande colchão é protagonista, seguido de uma série de fotografias pessoais do artista, de seu círculo de amizades e casamento (a riqueza deste material pode ser consultada no site do museu espanhol Guggenheim Bilbao $<$ http://ernestoneto.guggenheim-bilbao.eus/>).

De fato, o artista parece provocar no público um encontro que possibilita forçar o pensamento, tal como fala Deleuze (2006). Os signos que o artista cria ao proporcionar uma atmosfera diferenciada de interação provoca o pensamento do público e o desestrutura por um instante até que o pensamento o recomponha, todavia, não pela razão, mas pela sensação, o que transforma os espectadores também em artistas na medida em que eles passam a criar formas de se relacionar com a obra. A "verdade" passa a ser implicada e não absoluta.

O filósofo francês Gilles Deleuze já realizara uma denúncia ao modelo representacional e seus correlatos seja na arte, no senso comum ou no próprio pensamento (Deleuze, 2007). Para o filósofo, o senso comum constrói uma representação universal das coisas e do pensamento - um clichê -, sustentada por um certo paradigma que tem como base a filosofia de Platão. A relação estabelecida por este modelo é contemplativa e se apoia em valores transcendentes e universais procurando uma essência verdadeira, uma resposta dada de antemão.

Com efeito, a crítica do filósofo ao modelo da representação repousa na ideia de que pensar não é um ato de recognição, de reconhecimento ou de 
leitura de um mundo a priori. Pelo contrário, o pensamento nesta perspectiva é criação. Nas palavras de Deleuze (2009):

O que é primeiro no pensamento é o arrombamento, a violência, é o inimigo, e nada supõe a Filosofia; tudo parte de uma misosofia. Não contemos com o pensamento para fundar a necessidade relativa do que ele pensa; contemos, ao contrário, com a contingência de um encontro com aquilo que força a pensar, a fim de erguer e estabelecer a necessidade absoluta de um ato de pensar, de uma paixão de pensar. As condições de uma verdadeira crítica e de uma verdadeira criação são as mesmas: destruição da imagem de um pensamento que pressupõe a si próprio, gênese do ato de pensar no próprio pensamento (p. 203).

Deste modo, Neto consegue construir as "condições para uma verdadeira crítica e criação", onde o corpo não aparece mais como um obstáculo ao pensamento, mas como o próprio objeto do pensamento tal como fala Ulpiano (1996) com base na filosofia de Espinosa. Ulpiano (1996) apresenta a ideia de que o corpo se constituiu ao longo da história da filosofia em um obstáculo para o pensamento, na medida em que foi necessário banir o corpo para se pensar, ou seja, "seus erros, suas paixões, seus delírios" são necessariamente retirados da experimentação da razão (do pensar). Contudo, Ulpiano (1996) indica em Espinosa o primeiro marco em que o corpo deixa de ser um impeditivo ao pensamento para tornar-se "matéria prima do pensamento" (Ulpiano, 1996). Deste modo, ao considerarmos as forças ativas e reativas que produzem um corpo, de acordo com a filosofia nietzschiana, a vida passa a ser mais criativa ou afirmativa no sentido nietzschiano de que a vida ativa (afirmativa) é a que busca um estilo próprio, um estilo que não tem objetivo ou finalidade a não ser a de criar um estilo e produzir novas possibilidades (Ulpiano, 1996).

Então, a busca desse estilo passa a ser a busca da vontade afirmativa - produzir novas maneiras de pensar. Produzir o estilo é buscar novas maneiras de pensar. (...) O estilo é o rompimento do que está estabelecido. O estilo é uma complexão de contrastes, de confrontos, de alteridades, de diferenças (Ulpiano, 1996, parte II, 140 parágrafo).

Com efeito, Ernesto Neto produz seu estilo e com isto sua grande vontade afirmativa que instiga novas maneiras de pensar. $O$ artista rompe com aquilo que está já estabelecido no campo da escultura e produz seu próprio modo de esculturar que inclui sempre a suspensão e a interação. "O estilo é os confrontos das contrariedades, os enfrentamentos dos diferentes. O estilo é quando o homem rompe todas as regras que o governam, para se tornar um criador" (Ulpiano, 1996, parte II, $14^{\circ}$ parágrafo). Podemos dizer que o papel da clínica também deveria ser este: possibilitar aos sujeitos o resgate de sua força ativa, que cria e transforma a realidade atual.

Por outro lado, sua obra também cria espaços compostos pelo que podemos chamar de "entres". Ora, de acordo com Pelbart (1988) o fora é sempre um entre e uma vertigem do espaçamento, isto é, "a criação de um 
espaço pela diferença de um entre forças" (p.125). Com efeito, esta relação na obra do artista não é mediada por uma interioridade, como vimos. Na relação aqui proposta, o fora proporcionado pelo artista possibilita novos modos de forçar o pensamento a pensar, onde dois corpos são protagonistas. O artista retorna o corpo - e quando falamos corpo na obra de Neto, referimo-nos tanto ao corpo da obra de arte quanto ao corpo do espectador que a percorre - como objeto de sensação e de experimentação do qual ele foi "banido com experimentações assépticas, por insensibilização..." (Ulpiano 1996, parte I, 30 parágrafo).

Neste sentido, podemos retomar o trabalho de Crizel (2015) que afirma que uma pedagogia da sensação só é possível a partir desta sensação que nos povoa durante os encontros da vida. Tais sensações não podem ser representadas, mas vividas, por meio de signos que nos fazem pensar tal como explicita Deleuze (2007), mas um pensamento que não é o racional. Ele é vivido na carne, no corpo, mas no corpo que não é orgânico. Com efeito, é a partir desta relação onde não há sujeito e objeto delimitados, não há obra de arte e espectador isolados que a sensação e aprendizagem ocorrem. É uma atualização, uma força de pensamento.

\begin{abstract}
A sensação age sobre um corpo, que faz e se desfaz neste instante de experimentação deixando marcas na memória, mas não na memória - lembrança, cronológica, biológica - mas a memória vivida na carne. Experimentação que dissolve o corpo objetivo e subjetivo, criando outras subjetividades, maneiras de viver uma vida, uma formação. Um fora que habita um dentro e faz emergir uma diferença em si (Crizel, 2015, p. 43).
\end{abstract}

\title{
Quarta reflexão
}

Em nossa última reflexão, gostaríamos de problematizar a relação entre corpo e arte. É perceptível o quanto este novo paradigma estético que sustenta a arte contemporânea utiliza-se do corpo em seus processos artísticos. O corpo do espectador está sempre em contato direto ou indireto com a obra de arte, que pode ser, inclusive, o corpo do artista.

Ulpiano (1996) faz uma análise da obra de Cassavetes no cinema, onde todo seu empenho é em constituir um corpo cerimonial, que seria voltado para as posturas e expressões abandonadas pelo contexto histórico de submissão do corpo ao poder, aqui expressos pelos discursos científicos sobre o organismo e o orgânico. Ou seja, para o filósofo todo nosso modo de se colocar no mundo nossa postura, nosso andar - são representações de um sistema de poder historicamente determinado, pelo qual estamos submetidos. Todavia, há modos de romper com este modo habitual e é isto que Cassavetes chama de corpo cerimonial, um corpo que não possui uma história de representações (orgânicas, sociais, de hábito), mas toda a questão deste corpo é expressão.

$\mathrm{Na}$ literatura filosófica, com a qual eu trabalho, um corpo que se manifesta por atitudes, posturas e gestus chama-se corpo expressivo. 
(...) Um corpo que você não pensa mais por seus órgãos ou pela função dos órgãos. O objetivo não é compreender o corpo enquanto orgânico e com suas funções orgânicas - é um corpo inteiramente expressivo. É exatamente esse corpo que representaria a vida, porque já não seria um corpo submetido às leis do organismo (Ulpiano, 1996, parte I, 190 parágrafo).

Já em relação à obra de Neto, em suas próprias palavras: "acho que meu trabalho tem realmente uma questão de textura, de toque, de sexualidade, sensualidade, isto é, um entorno do corpo que tem muito a ver com a Lygia..." (Neto, 2008, p. 8). É assim que o artista passa a criar um certo corpo antropomórfico que pende de estruturas do teto presas somente a partir de nós e força da gravidade. A ideia do artista é colocar a Terra também como um grande organismo, como um corpo que interage com os seres humanos. "Precisamos ver a Terra como um corpo para termos com ela uma interlocução mais profunda, menos extrativista. A exposição [El cuerpo que me lleva, 2014] é calcada nesse pensamento" (Neto citado por Molina, 2014, $3^{\circ}$ parágrafo).

Assim, seguindo esta lógica o artista cria um espaço onde a pessoa não se enxerga como dentro ou fora dele, já que de antemão o artista afirma não haver espaço sem pessoas e nem pessoas sem espaço. O espaço, na visão do artista, é algo que está dentro e fora ao mesmo tempo. "Por exemplo, o trabalho do Panteão (Leviathan Thot, 2006), ele está pendurado em volta de você, que está sempre fora dele; você não ultrapassa aquela pele que faz o limite entre o dentro e o fora" (Neto, 2008, p. 11). É colocando este universo suspenso onde não sabemos o que é dentro e fora que o artista coloca o corpo como protagonista de sua obra. Os corpos são contornos, mas que possuem algumas fendas de abertura, onde cria-se um espaço de trânsito entre o interior e o exterior. Exemplos disso no corpo humano são a boca, o ouvido, a própria pele, etc. $\mathrm{Na}$ obra de arte, é a porta, a janela ou um túnel, e também a própria pele criada pelo artista que funcionam como espaços de transição.

Foi seguindo sempre esse estilo que o artista ficou conhecido pelas suas naves que funcionavam como lugares na galeria onde as pessoas poderiam adentrar as esculturas suspensas. O artista criou dispositivos que possuíam uma pele transparente e suspensa, mas pousada e inerte em relação com o mundo do público que o adentra.

Gutierrez Perez (2008) afirma o quanto a arte há uns dois mil anos atrás utilizava essencialmente do corpo em suas representações.

No primeiro sistema encontraríamos os antigos vestígios de sua representação nas pinturas rupestres, as quais dão testemunho da relação do homem com o meio ambiente; mais tarde, o corpo se deifica e protagoniza com fervor as cenas bíblicas que serviam para construir o imaginário coletivo, com relação à espiritualidade, reforçando assim como alternativa didática e de doutrinamento, isto é, com uma clara vocação utilitária. No segundo sistema se diversifica a abordagem da representação do corpo quanto às técnicas e - um 
aspecto importante - se incorpora a tecnologia para sua intervenção (Gutierrez Perez, 2008, pp. 275-276).

O corpo, portanto, sempre esteve presente na produção de arte ao longo da história. Todavia, as representações do corpo sempre estiveram ligadas ao contexto político e social da época. Alguns eram representados sem sexualidade, outros representados de modo esbelto. Enfim, representações religiosas, representações com uma exaltação às divindades e carnalidades do período grego, representações impressionistas. Por fim, em relação à arte contemporânea, o artista cria na relação do mundo com o seu corpo espaços e atmosferas onde o corpo do público certamente deve estar. Ele cria um ambiente sensorial, sobretudo, a partir de odores, tatos, onde todos os seus sentidos são convidados a participar. É o corpo do público como um todo que é chamado a interagir com sua obra de arte.

\section{CONSIDERAÇÕES FINAIS}

Com efeito, demonstramos como se dá a produção da arte contemporânea em relação a arte moderna que a precedia. Certamente, ficou claro o ponto de distinção entre uma arte contemplativa e uma arte interativa. Destarte, diversas transformações são necessárias à arte para que seja uma arte contemporânea, desde sua matéria-prima de produção até a sua exibição, de modo que o que o artista contemporâneo propõe não é apenas uma interação pela interação, mas uma interação onde o público é convidado a se retirar de seu lugar de costume para repensar e problematizar seu cotidiano a partir da arte. Assim, os próprios objetos de arte podem ser quaisquer coisas, dependendo da implicação que o/a espectador/a-artista os coloca.

Apresentamos, então, a obra do artista carioca Ernesto Neto que desde suas primeiras exposições já tinha influência da artista contemporânea brasileira Lygia Clark e sempre teve como objetivo um rompimento com o artificial, o representacional. O artista, por exemplo, nunca utilizou de colas ou soldas em suas obras. A maioria de seus trabalhos são suspensos e todos se utilizam da própria gravidade e de trabalhos manuais como o crochê e a costura. Além disso, o artista tem a pretensão de incluir o público em todos os pormenores das obras, realizando criações sensoriais, ou seja, suas obras são pensadas em relações com o corpo, destacando os sentidos que o/a interagente espectador tem ao adentrar sua obra, desde o olfato até o tato. Seus trabalhos são criados para que o público os atravesse, os habite e lá dentro experimente seu próprio corpo e sentidos.

Esses trabalhos (...) trabalhavam com o campo gravitacional e com a pele como lugar-metáfora do trânsito entre dentro e fora, expressivo, sensitivo, biológico, cosmológico e tal. Nesse momento, o pó atravessava a pele, e o odor expandia mais ainda esse campo (Neto, 2008, p. 12). 
Com efeito, a obra de arte para o artista é uma aferição do mundo, onde artista e espectador podem, em contato com a obra, repensar e problematizar sua relação com o mundo. Cada ato dentro da obra produz um resultado diferente, isto é, não existe uma resposta de antemão. Assim, o espaço é paradoxalmente um espaço de fuga do cotidiano para que o sujeito deixe de pensar e respire a própria vida, no entanto, pela sensação e não mais pela razão, podemos dizer que o sujeito é convidado a forçar o pensamento.

É uma virtualidade que se produz no fora e possibilita a real criação, já que é um fora que constitui um outro, modificando as maneiras de se olhar para o mundo. Deste modo, se abrir o pensamento para as forças do fora significa chamar a vida à transformação (Levy, 2011), acreditamos que Ernesto Neto o faz muito bem. Ele transforma suas esculturas em máquinas de guerra que deslocam o público de seu lugar habitual, resistindo ao mundo capitalista e trazendo o público para "pensar o pensamento" no aqui e agora.

\section{REFERÊNCIAS}

Bergson, H. (1979). A evolução criadora. Rio de Janeiro, RJ: Jorge Zahar. (Trabalho original publicado em 1907).

Bergson, H. (1990). Matéria e memória: Ensaio sobre a relação do corpo com o espírito. São Paulo, SP: Martins Fontes. (Trabalho original publicado em 1896).

Butler, J. (2003). Problemas de gênero: Feminismo e subversão da identidade. Rio de Janeiro, RJ: Civilização Brasileira. (Trabalho original publicado em 1990).

Braga, E. C. (2004). Arte e sensação: A natureza sintética da sensação na experiência artística segundo Gilles Deleuze. Revista Digital Art \&, 2(1), 19.

Crizel, A. P. (2015). Por uma pedagogia das sensações. In A. V. Munhoz, \& C. B. Costa (Eds.), Francis Bacon e nós: Corpo, diagrama, sensação (pp. 42-45). Lajeado, RS: Editora da Univates.

Deleuze, G. (2006). Proust e os signos. Rio de Janeiro, RJ: Forense-Universitária. (Trabalho original publicado em 1964).

Deleuze, G. (2007). Lógica do Sentido. São Paulo, SP: Editora perspectiva. (Trabalho original publicado em 1969).

Deleuze, G. (2009). Diferença e repetição. São Paulo, SP: Graal. (Trabalho original publicado em 1968).

Deleuze, G., \& Guattari, F. (1992). O que é a filosofia? Rio de Janeiro, RJ. (Trabalho original publicado em 1991).

Diamond, M. (1990). Sensation rising. Art Forum, 28(1), 122-125.

Feix, T. A. (2007). A inscrição do feminino/masculino na arte contemporânea. Revista Brasileira de Literatura Comparada, 10(1), 273-284. 
Foster, H. (2001). El retorno de lo real: La vanguardia a finales de siglo. Madrid: Ediciones Akal. (Trabalho original publicado em 1996).

Guattari, F. (1992). O novo paradigma estético. In F. Guattari, Caosmose: Um novo paradigma estético (pp. 127-148). Rio de Janeiro, RJ: Ed. 34.

Gutierrez Perez, P. O. (2008). Orlan: Un cuerpo proprio. La ventana, 3(28), 270293.

Levy, T. S. (2011). A experiência do fora: Blanchot, Foucault e Deleuze. São Paulo, SP: Civilização Brasileira.

Lopes, F. (2012). Ernesto Neto cria novas atmosferas em São Paulo. Blouinartinfo. Recuperado de http://br.blouinartinfo.com/news/story/817128/ernesto-neto-cria-novasatmosferas-em-s\%C3\%A3o-paulo

Mezan, R. (2007). Que tipo de ciência é, afinal, a Psicanálise? Natureza Humana, 9(2), 319-359.

Molina, C. (2014). Carioca ocupa Guggenheim de Bilbao: Museu ganha retrospectiva do artista Ernesto Neto. O Estado de São Paulo. Recuperado de http://cultura.estadao.com.br/noticias/geral,carioca-ocupa-guggenheimde-bilbao, 1125390

Morin, E. (2003). A necessidade de um pensamento complexo. In C. Mendes (Ed.), Representação e complexidade (pp. 69-78). Rio de Janeiro, RJ: Garamond.

Neto, E. (2008). A gente vai para o que ama - Entrevista. Arte \& Ensaios, 16(1), 6-25. Recuperado de http://www.ppgav.eba.ufrj.br/wpcontent/uploads/2012/01/ae16_entrevista_ernesto_neto.pdf

Pelbart, P. P. (1989). O pensamento do Fora. In P. P. Pelbart (Ed.), Da Clausura do Fora ao Fora da Clausura (pp.121-128). São Paulo, SP: Brasiliense.

Rivera, T. (2013). O avesso do imaginário: Arte contemporânea e psicanálise. São Paulo, SP: Cosaq-naif.

Rolnik, S. (1995). Subjetividade e História. Rua, 1(1), 49-61.

Rolnik, S. (1998). Por um estado de arte. A atualidade de Lygia Clark. In Fundação Bienal de São Paulo (Ed.), Núcleo Histórico: Antropofagia e Histórias de Canibalismos (pp. 456-467). São Paulo, SP: Editora da Fundação.

Rolnik, S. (2001). El arte cura? Quadernis Portatis, 2(1), 3-12.

Rolnik, S. (2015). Lygia Clark e o híbrido da arte/clínica. Concinnitas, 1(26), 104-112.

Sesc TV. (2014). "Museu Vivo: Ernesto Neto". Youtube. Adicionado por Sesc TV em 5 de fevereiro de 2014. Recuperado de https://youtu.be/ZZmJchHWpDw 
Teixeira-Filho, F. S. (2012). (Des)Articulações entre psicologia, arte e gêneros em busca da clínica das sensações. In G. H. Dionisio, \& S. J. Benelli (Eds.), Políticas públicas e clínica crítica (pp. 101-121). São Paulo, SP: Cultura Acadêmica.

Trizoli, T. (2008). O Feminismo e a Arte Contemporânea - Considerações. Anais do 170 Encontro Nacional da Associação Nacional de Pesquisadores em Artes Plásticas Panorama da Pesquisa em Artes Visuais (pp. 1495-1505). Florianópolis, SC: Anpap.

Ulpiano, C. (1996). Aula de 23/02/1996 - A vida criativa e a construção de um estilo.

Recuperado

de

claudioulpiano.org.br.s87743.gridserver.com/?p=6884

Sobre os autores

Fernando Silva Teixeira Filho é psicólogo pela Universidade Paulista, mestre e doutor em Psicologia Clínica pela Pontifícia Universidade Católica de São Paulo. Professor Livre Docente e vice coordenador do Programa de Pós-Graduação em Psicologia e Sociedade na Universidade Estadual Paulista "Júlio de Mesquita Filho", campus Assis. fsteixeirafilho@gmail.com

Murilo Galvão Amancio Cruz é psicólogo pela Universidade Estadual Paulista "Júlio de Mesquita Filho", campus de Assis. Atualmente é mestrando em Saúde Coletiva pelo Instituto de Medicina Social da Universidade do Estado do Rio de Janeiro. murilogac@gmail.com

Recebido em: 03/11/2016

Revisado em: 01/02/2017

Aceito em: 12/02/2017 